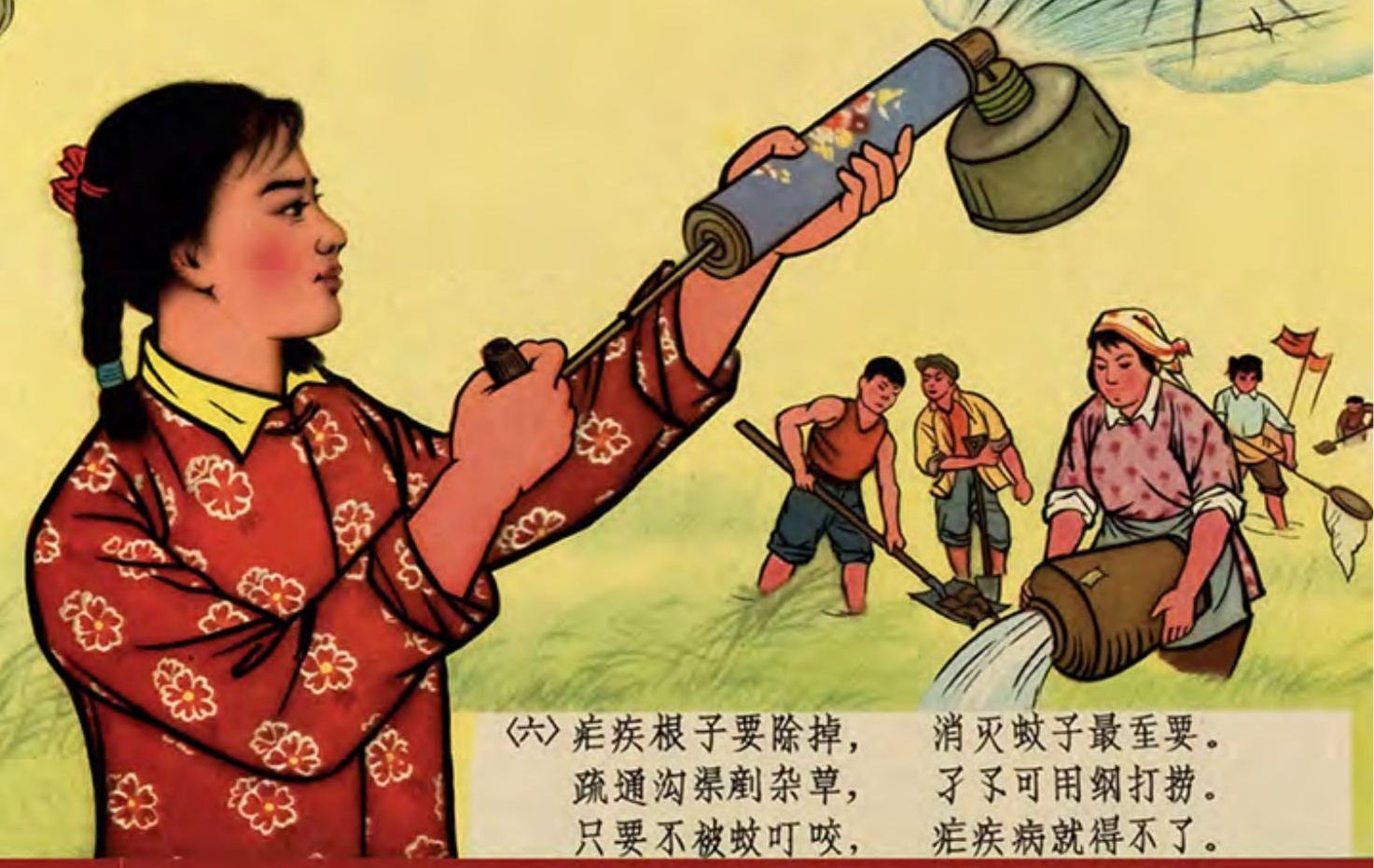

\title{
PUBLIC HEALTH AND THE MODERNIZATION OF CHINA, 1865-2015
}

Liping Bu 


\section{Public Health and the Modernization of China, 1865-2015}

This book, based on extensive original research, traces the development of China's public health system, showing how advances in public health have been an integral part of China's rise. It outlines the phenomenal improvements in public health, for example the increase in life expectancy from 38 in 1949 to 73 in 2010; relates developments in public health to prevailing political ideologies; and discusses how the drivers of health improvements were, unlike in the West, modern medical professionals and intellectuals who understood that, whatever the prevailing ideology, China needs to be a strong country. The book explores how public health concepts, policies, programmes, institutions and practices changed and developed through social and political upheavals, war, and famine, and argues that this perspective of China's development is refreshingly different from China's development viewed purely in political terms.

Liping Bu is a Professor of History at Alma College, Michigan, USA. 


\section{Routledge Studies in the Modern History of Asia}

113 Science, Technology, and Medicine in the Modern Japanese Empire

Edited by David G. Wittner and Philip C. Brown

114 Street Performers and Society in Urban Japan, 1600-1900 Gerald Groemer

115 Suicide in Twentieth Century Japan

Francesca Di Marco

116 Treaty Ports in Modern China Law, Land and Power Edited by Robert Bickers and Isabella Jackson

117 Kyoto Visual Culture in the Early Edo and Meiji Periods The Arts of Reinvention Edited by Morgan Pitelka and Alice $Y$. Tseng

118 Health Policy and Disease in Colonial and Post-Colonial Hong Kong, 1841-2003 Ka-che Yip, Philip Yuen-sang Leung, and Timothy Man-Kong Wong
119 Britain's Imperial Retreat from China, 1900-1931 Phoebe Chow

120 Constitution Making in Asia

Decolonisation and StateBuilding in the Aftermath of the British Empire H. Kumarasingham

121 Neutrality in Southeast Asia Concepts and Contexts Nicholas Tarling

122 Britain's Retreat from Empire in East Asia, 1905-1980 Edited by Antony Best

123 The Dismantling of Japan's Empire in East Asia Deimperialization, Postwar Legitimation and Imperial Afterlife Edited by Barak Kushner and Sherzod Muminov

124 Public Health and the Modernization of China, 1865-2015

Liping $\mathrm{Bu}$ 


\section{Public Health and the Modernization of China, 1865-2015}

Liping Bu 
First published 2017

by Routledge

2 Park Square, Milton Park, Abingdon, Oxon OX14 4RN

and by Routledge

711 Third Avenue, New York, NY 10017

Routledge is an imprint of the Taylor \& Francis Group, an informa business

(C) 2017 Liping $\mathrm{Bu}$

The right of Liping $\mathrm{Bu}$ to be identified as author of this work has been asserted by her in accordance with sections 77 and 78 of the Copyright, Designs and Patents Act 1988.

All rights reserved. No part of this book may be reprinted or reproduced or utilised in any form or by any electronic, mechanical, or other means, now known or hereafter invented, including photocopying and recording, or in any information storage or retrieval system, without permission in writing from the publishers.

Trademark notice: Product or corporate names may be trademarks or registered trademarks, and are used only for identification and explanation without intent to infringe.

British Library Cataloguing in Publication Data

A catalogue record for this book is available from the British Library

\section{Library of Congress Cataloging in Publication Data}

Names: Bu, Liping, 1960- author.

Title: Public health and the modernization of China, 1910-2015 / Liping Bu. Other titles: Routledge studies in the modern history of Asia (2005) ; 124.

Description: Abingdon, Oxon ; New York, NY : Routledge, 2017. | Series: Routledge studies in the modern history of Asia ; 124 | Includes bibliographical references and index.

Identifiers: LCCN 2016040347| ISBN 9781138845817 (hardback) | ISBN 9781315727912 (ebook)

Subjects: | MESH: Public Health-history | Health Policy-history | Health Planning-history | History, 20th Century | History, 21st Century | China Classification: LCC RA395.C53 | NLM WA 11 JC6 | DDC 362.10951—dc23

LC record available at https://lccn.loc.gov/2016040347

ISBN: 978-1-138-84581-7 (hbk)

ISBN: 978-1-315-72791-2 (ebk)

Typeset in Times New Roman

by Swales \& Willis Ltd, Exeter, Devon, UK 
In memory of my parents 
$\because$ Taylor \& Francis

Taylor \& Francis Group

http://taylorandfrancis.com 


\section{Contents}

List of illustrations $\quad \mathrm{x}$

Acknowledgements xi

List of abbreviations xiv

Primary sources $\quad$ XV

$\begin{array}{lr}\text { Introduction: modernization and public health } & 1\end{array}$

1 Public health: a modern concept of national power 25

Introduction 25

From salubrious cities to polluted treaty ports 27

Hygiene and public health: a divide of foreigners and Chinese 31

Missionaries and Western medicine 34

The Boxer Uprising, public health and modern reforms 38

Social Darwinism and national strength 43

The Manchurian plague and national sovereignty 47

Modern prevention measures and traditional social customs 49

Public health and Western medicine 55

Health education campaigns: public health and national strength 62

Government policy, modern medicine, and public health 72

Conclusion 77

Notes 81

2 Science, public health and national renaissance

Introduction 95

The Science Society of China and the new culture of science 96

Medical and social understanding of the human body 101

Peking Union Medical College: an American outpost

of medical science in China 108 
1917-1918 plague: epidemic prevention and popularization of science 113

John B. Grant and the training of public health professionals 118

Sanitary control, vital statistic collection, and tensions in the community 122

Maternal care and midwifery training 129

Health stations in urban and rural China 131

State medicine and national health 138

Conclusion 141

Notes 144

3 Building a modern health system: GMD's state medicine and CCP's people's health, 1920s-40s

Introduction 154

Part I: GMD's state building and health modernization 155

State medicine (公医): construction of a centralized national health system 155

Embracing international standards: formation of the Ministry of Health 159

National Quarantine Service: initial success of collaboration with the LNHO 162

Building the national health system with international assistance: the central institutions 165

Constructing local health institutions: the xian-centered rural health 169

Shortage of medical personnel and proposed medical education reform 173

Exclusion of Chinese medicine from health construction 176

Popular health movement: propaganda and education 178

School hygiene and health programs 185

Wartime health efforts 190

Part II: Health development at CCP revolutionary bases 192

Jiangxi soviet bases, 1927-1934 192

Health development of the Yanan era, 1936-1948 197

The anti-fascist movement and international medical aid 199

Development of health institutions 201

Medical education and training 203

Health and social reforms 205

Conclusion 208

Notes 212 
Introduction 222

Laying the foundation: national health policies and tasks (1949-1953) 223

The Patriotic Health Movement, literacy, and scientific socialist reconstruction 231

Uniting Chinese and Western medicines: a difficult road in the 1950s 235

Healthcare in urban and rural China 244

Rural health and barefoot doctors during the Cultural Revolution 250

Disease control and social transformation: cases of

anti-tuberculosis and anti-malaria campaigns 255

Conclusion 262

Notes 265

5 Economic reforms and new healthcare

Introduction 273

Marketization of economy and the collapse of socialist healthcare 274

Government efforts to reform and re-build the health system 280

Conclusion 288

Notes 290

Index 


\section{Illustrations}

\section{Figures}

1.1 Image of a gas company in Shanghai at the turn of the twentieth century 30

1.2 Image of lecture hall of public health 63

1.3 Wu Baoguang's chart of the health system 70

2.1 Fritz Kahn's man as industrial palace 105

2.2 "Human body is like a factory." Chinese Interpretation of Kahn's concept 106

2.3 Chinese advertisement of aspirin pills 107

2.4 Staff and students of Peking Union Medical College, 1921

2.5 Vernacular anti-plague notice, Beijing, 1918

2.6 Traveling Clinic, Gaoqiao, Shanghai, 1929

3.1 School hygiene organization and administration system 187

3.2 Tasks and contents of health classes 188

\section{Tables}

1.1 Population and death rates of Shanghai, 1887-1907 31

3.1 Local medical and health institutions, 1937-1947 160

3.2 Heads of Ministry of Health/National Health Administration, 1928-1949 161

3.3 Health lectures at inner city hospital of Beiping, 1930-1931 183 


\section{Acknowledgements}

This book has been a long time in the making. It started in 2001 when I was examining the YMCA archives at the University of Minnesota on a possible topic of physical education and national strength in early twentieth-century China. I had just completed a monograph, Making the World Like Us: Education, Cultural Expansion, and the American Century, and wanted to continue the research on American educational influence abroad. I was surprised to find, with great excitement, that the YMCA had engaged in active public health education in China, which had not been closely examined by scholars. In the following decade, I read and examined documents on public health at various libraries and archival centers in China, the United States, and the United Kingdom. I was fortunate that many local archives were opened up to the public in China and various grants enabled me to carry out the research.

In 2006, an Andrew Mellon fellowship at Needham Research Institute allowed me to do systematic reading and research on medicine and public health during my sabbatical at Cambridge University. I took the opportunity to broaden my knowledge by attending classes and lectures in the Department of History and Philosophy of Science at Cambridge. I am grateful to Professors Sir Geoffrey Lloyd and Christopher Cullen for letting me sit in their classes. The weekly reading seminar at Needham Research Institute was the best of its kind, where scholars shared their readings of original texts by translating, interpreting, discussing, and debating the accurate meaning of the original texts in translation. How do you translate daoyin (道引, a kind of Chinese yoga exercise) into English when there is no cultural equivalent to convey its meaning to a Western audience? The seminar deepened my appreciation of the practice of close reading of original texts in research and the emphasis of language and cultural proficiency in intercultural studies. Colleagues and friends at the NRI reading seminar will notice its sustained influence on me when they read the introduction paragraph of this book. With fond memories and deep appreciation, I thank John Moffett, Susan Bennett, and Christopher Cullen of the Needham Research Institute, and fellow researchers for the wonderful experience of shared intellectual pursuit and productive research.

The "Symposium on Global Health Histories" at the Natcher Conference Center on the campus of the National Institutes of Health in November 2005 was 
a turning point in the extension of my research into the second half of the twentieth century. The conference not only introduced me to the professional network of public health scholars but also to the new archival collection of Chinese public health at the National Library of Medicine. The health posters of the collection offered extraordinary visual and textual information on Chinese public health campaigns from the 1930s to the 1980s. I was fortunate to have the opportunity to work on the splendid health posters over several summers, during which I examined the data and gradually reshaped the design of my research and writing of China's public health movement and modernization. The visual images provided unique values of information as historical data. I am most grateful to Drs. Elizabeth Fee and Paul Theerman for the opportunity to work on the collection at the History of Medicine Division. The research also provided me delightful opportunities to collaborate with Liz Fee on several public health essays. I recall these wonderful productive summers with gratitude to Liz for the joyful writing of essays, and to the staff at the History of Medicine Division for their collegial support and friendship.

At the National Library of Medicine, I had the pleasant opportunities to attend formal lectures on the history of medicine and engage in casual lunch conversations with medical scientists on the campus of NIH. At one of the lunch conversations, a young medical scientist surprised me with the comment that “Chinese medicine (中医) has no science.” The implication was Chinese medicine had little value. When I told him that he sounded like those who wanted to abolish Chinese medicine in the 1920s, he conceded "maybe [it has] 30 percent of science." Non-Western medicine is still considered non-scientific by many in the scientific profession. Perhaps, a good educational effort is a way to reduce the bias of conventional impressions. In that regard, I was fortunate working with some staff members at the History of Medicine Division to curate several digital and physical exhibits on Chinese anti-disease health movements at the National Library of Medicine. I also created a higher education digital module on Chinese health campaigns in the twentieth century, which can be accessed at the National Library of Medicine. I hope these educational materials will help people better understand public health and Chinese medicine.

Local archives in China, especially the municipal archives of Beijing, Shanghai, and Nanjing, proved essential for my research. I am grateful for the professional assistance I received at the Chinese archival institutions and libraries. In particular, I thank the staff at Beijing Municipal Archives for their assistance with my research needs and their kindness of ordering lunch for researchers.

Over the years, I have shared my research with Chinese scholars and graduate students on various occasions. With deep appreciation of their support and for the opportunities, I thank Professor Zhang Daqing at Peking University, Professor Zhang Xianwen at Nanjing University, Professor Yu Xinzhong at Nankai University, and Professor Gao Xi at Fudan University.

The research of the book project also brought me in contact with many scholars in the unique field of history of medicine and public health at professional 
conferences in the United States, China, United Kingdom, and France. I had the good fortune of organizing several collaborative projects with scholars of different countries, including the "International Workshop on Public Health" at North Tarrytown in 2009, and the two volumes on Science, Public Health and the State in Modern Asia (2012) and Public Health and National Reconstruction in Post-War Asia: International Influences, Local Transformation (2014). Thanks to Darwin Stapleton, Jack Meyers, James Allen Smith and Camilla Harris at Rockefeller Archive Center for their support. Thanks to Darwin Stapleton and Ka-che Yip for sharing the editing work, and to each of the chapter contributors for sharing their latest research in the books on Asian public health.

When the China Medical Board was preparing book projects for its centennial celebration, I was honored to participate in the conferences in Boston and Beijing that led to the book, Medical Transitions in Twentieth-Century China. The conferences provided broad perspectives and stimulating intellectual discussions on the medical and public health development in the past century. I am grateful to Mary Bullock and Lincoln Chen at China Medical Board for the opportunities.

This book project has been supported by funding from various sources over the years. An Andrew Mellon Research Fellowship allowed me to do research at the Needham Research Institute, Cambridge, UK. A grant from the National Library of Medicine (G13LM009601-02) made it possible for me to receive valuable released time from teaching to work on this book. Grants-in-aid from the Rockefeller Archive Center supported my archival research at the Center. Alma College supported this project with annual faculty small grants and professional development funds. I acknowledge with great appreciation the various funding support. The content of this book, however, is solely my own responsibility and does not represent the views of any of the funding sources.

Portions of the text were published in journal articles and book chapters. I am grateful for the permissions of publishers from Peter Lang, University of Minnesota University Press, and Indiana University Press.

Many other people have given support and encouragement over the years. While I cannot list them all here, I'd like to thank Thomas Rosenbaum, Dagmar Getz, Ryan Bean, Bridie Andrews, Marta Hanson, Socrates Litsios, Nicole Elizabeth Barnes, Thomas Dubois, Zhen Cheng, Fang Xiaoping, Jiang Yuhong, Zhang Xia, Alyssa Walters, Gloria Tseng, Ba Ba Zhang, Ginny Roth, Doug Atkins, Lorreta Tang, Jacque-Lynn Shulman, Lois Cohen, and Susan Speaker. Thanks also to Michael Selmon the provost, colleagues, and library staff at Alma College.

Special thanks to Peter Sowden at Routledge. His encouragement and interest help to sustain the progress of this book project. Thanks to Laura Christopher and her team for their detailed attention and excellent work in the production of this book. Thanks to Ting Baker, whose copy-editing skills improved the quality of the book. 


\section{Abbreviations}

$\begin{array}{ll}\text { CCP } & \text { Chinese Communist Party } \\ \text { CEPB/NEPC } & \begin{array}{l}\text { Central Epidemic Prevention Bureau/National Epidemic } \\ \text { Prevention Bureau }\end{array} \\ \text { CFHS } & \text { Central Field Health Station } \\ \text { CMA } & \text { Chinese Medical Association } \\ \text { CMB } & \text { China Medical Board } \\ \text { CMMA } & \text { China Medical Missionary Association } \\ \text { GMD } & \text { Guomindang, Nationalist Party } \\ \text { IHB/IHD } & \text { International Health Board/International Health Division } \\ \text { JPHA } & \text { Jiangsu Public Health Association } \\ \text { LNHO } & \text { League of Nations Health Organization } \\ \text { MEM } & \text { Mass Education Movement } \\ \text { NHA } & \text { National Health Administration } \\ \text { NMAC } & \text { National Medical Association of China } \\ \text { NRCMS } & \text { New Rural Cooperative Medical System } \\ \text { PUMC } & \text { Peking Union Medical College } \\ \text { RAC } & \text { Rockefeller Archives Center } \\ \text { RF } & \text { Rockefeller Foundation } \\ \text { SMC } & \text { Shanghai Medical College } \\ \text { YMCA } & \text { Young Men’s Christian Association }\end{array}$




\section{Primary sources}

\section{Archives}

Annual and Quarterly Reports of Field Secretaries of the YMCA, Kautz Family YMCA Archives, University of Minnesota, St. Paul, Minnesota, USA.

Beijing Metropolitan Police Archives, Beijing Municipal Archives, Beijing, China.

Beiping Education Bureau and School Health Archives, Beijing Municipal Archives, Beijing.

Beiping Health Bureau Archives, Beijing Municipal Archives, Beijing.

Beiping Social Bureau Archives, Beijing Municipal Archives, Beijing.

Beiyang Government Archives, the Second Historical Archives of China, Nanjing, China.

Biographical Files, Kautz Family YMCA Archives, University of Minnesota Libraries, St. Paul, Minnesota.

China Medical Board Inc. Archives, the Rockefeller Archive Center, North Tarrytown, New York, USA.

Chinese Collections, Cambridge University Library, Cambridge, UK.

Chinese Public Health Collection, National Library of Medicine, National Institutes of Health, Bethesda, Maryland, USA.

East Asian History of Science Library, Needham Research Institute, Cambridge, UK. Health Ministry of the Nationalist Government Archives, the Second Historical Archives of China, Nanjing.

Health Station, PUMC Archives, Beijing Xiehe Medical University, Beijing, China.

International Health Board/Division Archives, Rockefeller Archive Center, North Tarrytown, New York. 
xvi Primarysources

James Earl Russell Papers, Teachers College Special Collections, Columbia University, New York, USA.

John B. Grant, Public Health Department, PUMC Archives, Beijing Xiehe Medical University, Beijing.

Letters and Correspondence of YMCA Field Secretaries, Kautz Family YMCA Archives, University of Minnesota, St. Paul, Minnesota.

Minguo wenxian [Literature on the Republic of China], Nanjing Library, Nanjing, China.

Liu Ruiheng Papers, PUMC Archives, Beijing Xiehe Medical University, Beijing.

Medical and Public Health of China, the National Archives, Kew, Surrey, UK.

Nanjing Municipal Government Archives, the Second Historical Archives of China, Nanjing.

Paul Monroe Papers, Teachers College Special Collections, Columbia University, New York.

Police Department Archives, the First Historical Archives of China, Beijing.

Public Health Archives, Nanjing Municipal Archives, Nanjing.

Public Health, Tianjin Municipal Archives, Tianjin, China.

Public Health Practice in Counties and Village Towns, Jiangsu Provincial Archives, Nanjing.

Public Health, Shanghai Municipal Council, Shanghai Municipal Archives, Shanghai.

Rockefeller Foundation Archives, the Rockefeller Archive Center, North Tarrytown, New York.

Shanghai Municipal Council Minutes, Shanghai Municipal Archives, Shanghai.

Shanghai Sanitation and Hygiene, Shanghai Municipal Archives, Shanghai.

Special Municipality of Beiping Archives, Beijing Municipal Archives, Beijing.

The Executive Yuan of the Republic of China Archives, the Second Historical Archives of China, Nanjing.

The Reminiscences of Dr. John B. Grant, Columbia University Oral History Project, Columbia University, New York, USA.

\section{Reports, journals, yearbooks, and newspapers}

Annual Report of the Central Epidemic Prevention Bureau, Beijing Annual Report of the Health Organization of the League of Nations 
Annual Report of the Rockefeller Foundation

Boston Evening Transcript

Chinese Medical Journal

Dagongbao

Dongfang zazhi [Eastern Miscellany]

Fanglao tongxun [Anti-Tuberculosis Newsletter]

Hankou ribao

Huadong weisheng [East China Health]

Kexue [Science]

Milbank Memorial Fund Quarterly Bulletin

Peking Gazette

Quarterly Bulletin of the Health Organization of the League of Nations

Renmin ribao

Report of the National Quarantine Service, Shanghai

Shengjing shibao

The China Medical Journal

The National Medical Journal of China

The New York Times

The World's Work

Xin Zhongguo funü [Women of New China]

Xin zhongyiyao [New Chinese Medicine]

Xinhua yuebao

Xin qingnian [La Jeunesse, The New Youth]

Zhongguo yaoxue zazhi [Chinese Journal of Pharmacy]

Zhonghua yishi zazhi [Chinese Journal of Medical History]

Zhonghua yixue zazhi (Chinese and English versions)

\section{Collections of documents}

Beijing shi zhongyao wenxian xuanbian (1952) [Selection of Important Documents of Beijing Municipality, 1952]. Zhongguo dang'an chubanshe, 2002.

Collection of Historical Documents of the Public Health Department of Shanghai Municipal Council, multi volumes, Shanghai Municipal Archives. 
Dangdai Zhongguo de weisheng shiye [Health of Contemporary China]. Beijing: Zhongguo shehui kexue chubanshe, 1986.

Dangdai Zhongguo weisheng dashi ji (1949-1990) [Major Events of Health Work in Contemporary China, 1949-1990]. Renmin weisheng chubanshe, 1993.

Jianguo yilai Mao Zedong wengao [Manuscripts of Mao Zedong since the Founding of the People's Republic of China]. Zhongyang wenxian chubanshe, 2000.

Jianguo yilai zhongyao wenxian xuanbian [Selection of Important Documents since the Founding of the People's Republic of China]. Zhongyang wenxian chubanshe, 1993.

Mao Zedong shuxin xuanji [Selection of Mao Zedong's Correspondence and Letters]. Zhongyang wenxian chubanshe, 2003.

National Health Statistics. Beijing: Ministry of Health, 2002.

Selected Works of Mao Tse-tung. Peking: Foreign Language Press, 1967.

Weishengbu jicheng weisheng he fuyou baojian si [Bureau of Basic Health and Maternal and Children's Health of the Health Ministry], Nongcun weisheng wenjian huibian (1951-2000) [Collection of Documents on Rural Health Work, 1951-2000]. Zhonghua renmin gongheguo weishengbu, 2001.

Xin Zhongguo yufang yixue lishi ziliao xuanbian (1) [Selection of Historical Documents on Preventive Medicine of New China, vol. 1]. Beijing: Renmin junyi chubanshe, 1986.

Zhongguo nueji de fangzhi yu yanjiu bianweihui [Editorial Committee on Malaria Prevention and Research in China], Zhongguo nueji de fangzhi yu yanjiu [Malaria Prevention and Research in China]. Beijing: Remin weisheng chubanshe, 1991.

Zhongguo weisheng nianjian [Health Yearbook of the People's Republic of China]. Beijing: Renmin weisheng chubanshe, 1997.

Zhongguo weisheng tongji nianqian [Annual Medical and Health Statistics of China]. Beijing: Zhongguo xiehe yike daxue chubanshe, 2009.

Zhongyi gongzuo wenjian huibian (1949-1983) [Collection of Documents on Chinese Medicine Work, 1949-1983]. Zhonghua renmin gongheguo weishengbu, 1985.

Zhongyi gongzuo ziliao huibian [Collection of Documentary Materials on Chinese Medicine Work]. Zhonghua renmin gongheguo weishengbu, 1956. 


\title{
Introduction
}

\section{Modernization and public health}

\begin{abstract}
The science of hygiene is originated in Europe. Westerners claim that the more civilized a country and the more important a nation, then the more sophisticated their laws of hygiene are; of the opposite is a weak country and an inferior people. ${ }^{1}$
\end{abstract}

Thus began the article "On Hygiene" in the popular Chinese magazine, Dongfang zazhi (东方杂志, Eastern Miscellany), in 1905. The author discussed the importance of hygiene and modern medicine in relation to China's future, and made the argument that hygiene, on a small scale, affected the health of individuals and families, but on a large scale, defined the fate of a country and its people. He put hygiene squarely in the equation of the advancement of a country and the quality of a people. In the article, the author lamented the decline of Chinese medical development and the sanitary neglect by the people and the officialdom, which, in his opinion, led to the status of a weak China. This point of argument was common among Chinese modernizers who regarded hygiene and modern medicine essential elements of a strong and modern China. After the 1895 SinoJapanese War, China was portrayed as "the sick man of Asia," a humiliating metaphor previously used to describe the declined Ottoman empire. ${ }^{2}$ Writings of Western missionaries and newspapermen also popularized that China was a filthy and disease-ridden backward country that needed Western "progressive" forces to transform it. Chinese modernizers including intellectuals, officials and urban merchants, out of admiration of the advancement and power of the West and concerns over China's plight in the struggle against foreign dominance, understood hygiene and public health in light of national strength. They urged the Chinese government to emulate the West to create a clean and healthy nation to join the modern world. Scholars have examined the subject of hygiene and public health from different perspectives. Ruth Rogaski analyzes that hygienic modernity had deeper implications of racial prejudice and social and cultural biases. ${ }^{3} \mathrm{Hu}$ Cheng points out that foreigners and Chinese had different narratives of the "unsanitary" China, which showed that perceptions of foreigners were closely tied to their attitude of Western cultural superiority whereas Chinese views were intertwined with China's struggle to modernize and maintain national sovereignty. ${ }^{4}$ 


\section{Introduction}

The idea of a clean and healthy nation gained significant social and cultural meanings in the late nineteenth and early twentieth centuries when the West was energized by the social reforms of hygiene and sanitary movement. Cleanliness defined the advancement of a civilized nation and the virtues of modern citizens in terms of good morals, physical health, and cultured manners. The opposite indicated the backwardness of a weak uncivilized country and the lack of moral virtues of individuals. In dissecting the power of the concept of civilization in modern history, Brett Bowden exposes it as a stage-managed account of history that legitimizes imperialism, uniformity, and conformity to Western standards. ${ }^{5}$ He argues that the idea of civilization has been deployed to dichotomize peoples, cultures, and histories to justify all manner of interventions, aggressive colonization, and sociopolitical engineering in the history of the West. Nonetheless, cleanliness became a hallmark of modern citizens and "civilized" societies, while uncleanliness and high death rates characterized "uncivilized" societies. China, India, and Egypt — countries of distinct ancient civilizations - were defined as uncivilized in contrast to the "civilized world" of the West. Newspapers and popular magazines helped spread the image of these countries as unclean and uncivilized societies in the public mind to construct the divide of the advanced West and the backward non-West. Chinese elite and modernizers, who bought into but were anxious to change the dichotomy, used the power of media to disseminate information of hygiene and public health and compel Chinese people to take action and clean up the image of an unsanitary China. ${ }^{6}$ The discourse of cleanliness was integral to the repertoire of modernity and national rejuvenation throughout twentieth-century China. It projected the prospect of a nation and people emerging from the old society of dark and sickly ignorance into the bright and healthy enlightenment of human advancement.

Chinese hygiene and public health movement started differently from the Western movement in terms of circumstances, motivations and purposes. Europe and America began the sanitary and public health movement as social reforms to address the problems of filth, poverty and epidemic diseases brought on by industrialization, with the purpose of achieving economic efficiency and productivity and humanitarian improvement of the working poor. Voluntary associations of concerned citizens played important pioneering roles in getting the local and national governments involved to take on the responsibility of sanitation administration and public health in Western nations. ${ }^{7}$ Chinese promotion of sanitation and public health was initiated by intellectuals and modern medical professionals who sought to modernize China to transform old institutions and to change people's social and political thinking and behavior. They were not motivated by the concerns of economic loss of diseased people to national power as the West did, but by the concerns of China's decline and inability to keep its sovereignty in encountering the aggressive foreign powers. Public health advocates promoted modern medicine and public health as a spearhead to change China from a weak traditional society into a strong modern nation.

The history of Chinese public health modernization was intertwined with the major events of China's political, cultural and social developments. The public health 
movement promoted science as the central force of modernization to transform China. Emphasis on science helped shape the rhetoric of the Chinese public health movement and facilitated the dissemination of scientific knowledge of disease and modern medicine. Moreover, public health and scientific knowledge were promoted in relation to the political, social and cultural needs of reforms and revolutions that had been led by various groups who held different ideological convictions. In the endeavor to make China modern and strong over the long decades of the twentieth century, different political beliefs and competing visions of a modern China only enriched the various modes or paradigms of modernity to be applied to the reconstruction of China from the late Qing to the current era of reforms. The paradigm of modernity during the Republican era (民国时期) was informed by anti-imperialist nationalism and Social Darwinian concepts of competition and adaptation. Modernization meant imitation of Western institutions and emphasis on science as the core value of culture. The socialist paradigm of the People's Republic of China (PRC) was guided by a clear theoretical framework with the Soviet experience initially used as the model of state-building and national development before a Chinese model of socialist modernization was created in the Mao era. The post-Mao economic reforms emphasized the four modernizations as the paradigm of modernity by shifting to a system of market economy to achieve national prosperity and power.

The late Qing government adopted the “New Policy” (新政) of reforms to modernize the polity in 1901 under both domestic and foreign pressures. Institutional modernization included the establishment of the first public health agency of China, the Beiyang Sanitary Service, in 1902. Social Darwinian thought dominated the intellectual persuasion of the urgent needs to reform the system and to change the culture. The tensions within the society and Qing's inability to effectively carry out reforms led to its fall in the 1911 revolution, which ended the two-thousand-year-old dynastic system and created a republic political system. The revolutionary acceleration of institutional change of modernization saw the introduction of more public health measures and the support of popular health education, the most significant of which was the legislation on notifiable diseases by the government and the health education campaign by social and professional organizations. The Beiyang government (北洋政府) of the early Republic projected its progressive image by promoting sanitation and public health in a changing society, but the commitment to building a modern health system did not come until the establishment of the Nationalist government in Nanjing in 1927. The Nationalist government created a Ministry of Health in 1928 in accordance with the organizational standards of modern nations and propagated Sun Yat-sen's three people's principles as the paradigm of modernization. ${ }^{8}$ A close examination of government propaganda materials reveal, however, that a strong antiimperialist nationalistic argument informed by both Social Darwinian concepts and modern science was popularized in the health education and national development campaigns. Moreover, modern medical professional elite, rather than the political leaders, worked as the true driving force of the institutionalization of a health administrative system in the Nationalist era, opting to follow the state medicine model to solve China's huge health challenges. When the PRC was 
established in 1949, a socialist paradigm of modernization was applied to reconstructing China and building a people's healthcare system with the provision of free healthcare to the vast urban and rural population. The system, however, was fundamentally changed with economic reforms since the 1980s. The introduction of market forces to the economy helped create enormous wealth for the nation, but the market reform of the health system resulted in unaffordability and inaccessibility of healthcare, seriously eroding the vision of a fair and just society that the government set out to build. The current government is committed to deepening the health system reform and continues to search for a health system that will be affordable and accessible with provision of primary healthcare to everyone.

This book on public health provides a focal point to examine the long process of modernization of China from the late Qing to the current era of reforms in a global context. It investigates not only domestic political, social and cultural transformations but also China's relations with the larger world. Buzan and Lawson recently made the argument that industrialization, modern state-building, ideologies of nationalism, socialism and racism, and the destabilization of balance of power fundamentally contributed to the global transformation in the nineteenth and twentieth centuries. ${ }^{9}$ Such an argument can be readily applied to the transformation of China as a case study, as these elements influenced China's modernizations and its interactions with other countries and international organizations. The hygiene and public health modernization, which was part and parcel of modern state-building and national development, was a politicized endeavor that intertwined with Chinese reforms and revolutions in a broad sense. It encompasses the change of people's mentality and behavior and the reconstruction of institutions and political systems of a modern state. From Social Darwinian views and the discourse of "the sick man of Asia" through the revolutions to the rise of China again, national health has been the image and the substance of the modern transformation of China.

My examination of public health modernization concentrates on diseaseprevention, healthcare, reforms and revolutions, and modern reconstruction of China. It does not deal with anti-opium and anti-smoking movements, which are important subjects of public health that merit separate treatments. ${ }^{10}$ In this book, I use the plural form of "Western and Chinese medicines" to mean not only different drugs but also different systems of medicine. The term "Western medicine” (xiyi, 西医) has been used interchangeably with "modern medicine," "new medicine," and "scientific medicine" in modern China, and this particular feature is reflected in the writing of this book. Similarly, the Chinese term “weishing, 卫生” is used broadly to convey the meanings of hygiene, sanitation, and health. The word "health" has been used in Chinese documents as "jiankang, 健康,” “weishging, 卫生,” and “baojian, 保健” at different historical times and different contexts, as school health has been translated as "xuexiao jiankang, 学校健康,” and “xuexiao weishing, 学校卫生,” and people’s health has been translated as “renmin jiankang, 人民健康,” “renmin weisheng, 人民卫生,” and “renmin baojian, 保健.” The term “public health” is usually translated as “gonggong weisheng, 公共卫生” or “weisheng, 卫生.” A few themes have emerged to illuminate the interplays of different parallels of events in this extensive study of public health and the modernization of China. 


\section{International and transnational influence}

Westerners considered Chinese cities salubrious and Chinese people healthy in comparison with those in Europe and America in the mid-nineteenth century when China had fewer of the epidemics that plagued Western industrial cities. The picture changed after industrial factories were increasingly built in treaty port cities after 1860s. Western nations had opened up Chinese ports for trades and factories with wars and unequal treaties since China lost the war over British opium traffic in $1842 .{ }^{11}$ Urban squalor, slums, poverty and disease had grown along with modern industries, as factories expanded into farming lands and shanty towns emerged near the factories. Western missionaries were known as the first critics of Chinese unsanitary conditions but they were less known for being amazed at the hygienic habits of Chinese people who had the tradition of using boiled water and having public bathhouses. Missionaries carried to China the modern ideas of sanitation and disease prevention that were developing in their home countries in the nineteenth century. They promoted and practiced modern medicine to open up China for evangelization, and initiated hygiene education and disease prevention in places where they exercised broad influence. In propagating Christianity and Western culture, they promoted Western medicine as the scientific medicine and criticized Chinese medicine as unscientific superstition to negate the value and relevance of traditional culture in modernity. Since knowledge of hygiene and disease prevention was part of modern medicine, the dissemination of health knowledge further helped legitimize Western medicine as the true knowledge to challenge Chinese medical knowledge. The popular health education campaigns in the 1910s brought modern hygiene and disease prevention to a wide range of Chinese social classes and places as they were held in major cities across China. The campaigns were organized and conducted in collaboration with local governments by medical missionaries, the YMCAs, and Western-trained Chinese doctors of modern medicine. These three groups formed the Joint Council on Public Health Education in 1916 (renamed Council on Health Education in 1920) to lead the week-long health education campaigns in different provinces to promote Western medicine and public health. Missionaries' interest in health education was initially driven by their zeal to evangelize China but their enthusiasm tapered off when the campaigns took on a new life as a health education movement. Chinese local governments sponsored the campaigns with financial and human resources while the Council provided the technical expertise and educational materials. In each city where the campaign took place, students, teachers, officials, missionaries and YMCA secretaries were mobilized to help organize and lead the health lectures and the explanation of health exhibits, which attracted people of all walks of life. Tens of thousands of urban residents, men and women, attended the health education campaigns as major events in their cities. Visual materials and illustrations, such as pictures, posters, charts and diagrams, helped disseminate information about the cause of disease, flies as the agents to spread disease, and the importance of hygiene and health in relation to individual well-being and national strength. The health education campaigns helped raise public awareness, particularly those in cities, 


\section{Introduction}

about the individual's ability to prevent disease and keep healthy. Moreover, the campaigns sometimes conducted smallpox vaccination and contributed to the development of a modern public health discourse in Chinese society before the training of public health professionals was established at medical schools. The key leader of the campaigns, William Wesley Peter (known as W. W. Peter), who was a YMCA secretary with unique talents of health showmanship, urged Chinese participants to think of education, laws, and statistics as the main building blocks to the foundation of public health in China. The Council bequeathed a large collection of visual health education materials and a rich legacy of methods to popularize health knowledge. For his significant beneficiary contribution to China, Peter was recognized by the Chinese government with a 5 th class medal of the Order of Golden Grain (wudeng jiahe zhang, 五等嘉禾章). ${ }^{12}$ John D. Rockefeller, Jr. received the same type of medal for his contribution to China by building the Peking Union Medical College (PUMC). ${ }^{13}$

The Rockefeller philanthropy came to China immediately after the 1911 revolution, with investigations of the health and medical conditions of China. When the Rockefeller Foundation (RF) was formed in 1914, it envisioned modernizing China with medical science by establishing a world-class medical college, Peking Union Medical College, to spearhead the modern medical enterprise in China. For that purpose, the RF created a China Medical Board (CMB) to take charge of PUMC and related matters. PUMC was built upon the medical school that Anglo-American missionaries had created and run for over a decade. Rarely did a transfer of the ownership of a medical school from the missionary to the philanthropist impact the future of an entire nation's medical and health profession in such a degree as the PUMC, for the college produced a small but influential group of elite medical professionals who eventually dominated Chinese medical education and health administration. The thrust of the Rockefeller medical enterprise signified the beginning of an end of the missionary-dominated modern medical education and the rise of secular education of medical science in China. It ultimately helped shape the creation of China's national health system, with John B. Grant and the PUMC circle playing the key role in the Nationalist government. The CMB and PUMC epitomized RF's influence in China, just as Standard Oil and YMCA embodied the American influence in China, in the first half of the twentieth century. ${ }^{14}$

The RF introduced modern medical science and public health knowledge to the training of Chinese medical students while using China as a medical laboratory to study diseases and health problems. With medical reform taking place at home in the United States, the RF found the power of medical science an ideal tool to advance mankind in a global scheme of transforming traditional "backward" societies via sanitation and disease control. Medical colleges and institutions and health programs were established in different countries across the globe, under the direction and supervision of the International Health Board (IHB, which became the International Health Division in 1927, IHD). ${ }^{15}$ In order to publicize modern medicine and recruit students to study it, CMB enlisted the help of W. W. Peter and the Council on Health Education to a campaign to 
promote modern medicine among students to encourage them to take modern medicine as life work. In the meantime, medical scientists of the RF, who had low regard for the standard of medical education at missionary schools, tried to set up as rigorous a standard as the best American medical college would expect for the faculty and students at PUMC. They even made English the language of instruction, all in the name of upholding scientific standards. The PUMC produced a total of 321 medical doctors from 1921 to 1943 (World War II disrupted its operation), and graduated 279 nurses from 1924 to $1950 .{ }^{16}$ Many of this small elite group became key leaders of the Nationalist health administration system and at medical institutions of research and education. With the production of such a small number of medical professionals, the RF's China medical enterprise barely made a difference in bringing the benefits of modern medical science to ordinary Chinese people. The RF's major influence in China lay in its contribution to medical education and the leadership of a modern health administration system, thanks particularly to the pivotal role played by John B. Grant.

Grant worked in China for 17 years from 1921 to 1938 as head of the Hygiene and Public Health Department at PUMC and the China representative of the IHB/IHD of the RF. His profound interest in and commitment to public health, facilitated by his extensive network and close relations with Chinese medical and political leaders, led to his exceptionally fruitful career in training public health leaders and shaping the development of a national health system in China during the tumultuous years of political instability and uncertainty. It is not an exaggeration that Grant, to a great extent, provided the continuity of guidance in public health professionalization and modernization from the Beiyang decade to the Nanjing era. He served, by invitation, as the advisor to the Chinese government in all matters pertaining to health, while he worked at PUMC. Grant's major contributions were not just his creation of public health programs and his influence in the development of a national health administrative system of the Nationalist government. More importantly, his teaching and promotion of the ideas of state medicine, social medicine and preventive medicine left indelible imprints in the Chinese health profession. His ideas and methods of public health education have exerted a long-term influence in China under different political systems.

Grant also played an important role in advising and facilitating the involvement of the League of Nations Health Organization (LNHO) in the modernization of China's health system and national development. From the initial negotiations to establish a National Quarantine Service in the 1920s to the building of a national health administrative system in the 1930s, the LNHO provided China not only assistance of professional expertise and the training of personnel but also the support of financial resources. The League of Nations' involvement even expanded beyond the health field to various aspects of economic planning and construction of China before it was disrupted by the outbreak of World War II. ${ }^{17}$ Throughout, Grant and the RF worked with the League's representatives to influence China's national health programs and to provide parallel assistance of training and financial support, even though the LNHO leaders tried to distance themselves from the RF to retain more independent approaches to China's health 


\section{Introduction}

modernization. The League's involvement positively influenced, to a certain extent, China's successful negotiations with foreign powers over its maritime sovereignty and the institutional building of a state medicine system.

While the Nationalist government was assisted mostly by the RF and the LNHO in its health modernization, the CCP government received international aid from different supporters in its health development. During the Yanan era, international health teams and individuals came from different countries to help the CCP in the anti-fascist movement of World War II. They brought not only advanced medical equipment but more importantly the badly needed medical expertise, which significantly helped improve the battle field medical service and the training of CCP medical personnel. With the victory of CCP over the Nationalists in the civil war (1946-1949) and the establishment of the PRC in 1949, the Soviet Union became a key influence in China's health reconstruction as well as national development in a broad sense. The Cold War had shaped the world into a bi-polar international order and China's participation in the Korean War made the United States an impossible model of development. The Soviet emphasis on preventive medicine, which had attracted the attention of Chinese health professionals in the 1930s-1940s, was now promoted by Chinese political and health leaders across the country. Although the emphasis on prevention had long been the health policy of the CCP, prevention of disease was incorporated into national defense in the new Patriotic Health Movement in the early 1950s as measures to defeat the alleged American germ-warfare during the Korean War. The Chinese health movement was a politically mobilized patriotic mass movement for disease prevention, national defense, economic productivity, and socialist reconstruction.

Economic reforms of the past three decades fully integrated China into the world, where major international organizations, such as the World Health Organization (WHO), World Back, International Monetary Fund (IMF) and United Nations organizations, worked with the Chinese government in the restructuring of the economy, health, and other aspects of social development. In regard to the health sector reforms, American influence was significant in shaping a new health insurance system to replace the socialist people's healthcare. But the American model has not been working well in China, and the government introduced a new plan of health system reform in 2009 with the intention to build a health system with provision of primary healthcare to everyone. The search is still going on for a healthcare system suitable for the socioeconomic conditions of the Chinese market economy, as the government deepens the reform of the health system.

\section{Chinese modernizers, modern medicine, and public health}

Edmund S. K. Fung argues that the interactions of three major trends of intellectual orientations, namely liberalism, conservatism, and socialism, underpinned the cultural and political modernity of China. ${ }^{18}$ Marketization of the economy is apparently economic liberalism that underlies the current construction of Chinese 
modernity. Of all the different political and intellectual persuasions of twentiethcentury China, there was a shared common goal of building a strong modern state with national unity. The semi-colonial status of China at the end of the nineteenth century resulted from constant foreign encroachment and the continuous decline of the Qing empire. The contrast of clean streets and bright tall buildings in the foreign settlements to the filthy and muddy streets and shanty towns in the Chinese sections in many treaty ports stimulated Chinese modernizers to seek fundamental reforms by learning from the West. The late Qing reformists, such as Yan Fu and Liang Qichao, noticed that Western nations all emphasized physical education of the people and promoted public health. They advocated physical fitness of the masses as one of the fundamental means to regain China's national strength. To the reformists, the hope of national revival lay in the training of Chinese people into new citizens of strong moral virtues, intelligence and physical fitness capable of defending their country and competing with other nations. Their thinking was profoundly influenced by Social Darwinian interpretation of a world of competing nations where the strong and superior (优) would survive and the weak and inferior (劣) would be weeded out. The meaning of “competition" and "evolution” was understood on both personal and national levels when foreign powers were carving up China into their spheres of influence. The individual to the national body was cast in the relation of the cell to a social organism in an evolutionary process of "survival of the fittest." 19

Medicine was supposed to save people's lives and better the society, and medical modernization was thought an essential step towards reviving China. Sun Yat-sen and Lu Xun, for instance, both started their career by studying modern medicine, though each in their own ways realized that a fundamental change of China needed something more revolutionary than what modern medicine could offer. The issue of medicine and public health was played out in the larger context of political and social revolutions of China. Hence, modern public health was intertwined with Chinese nationalist struggle against foreign imperialist dominance and the transformation of the traditional Chinese society into a modern nation. Western medicine offered the science of prevention, and germ theory provided the powerful explanation that pinpointed the cause of disease; whereas Chinese medicine lacked the quality of modern medicine to zero in on one single cause of disease, but used instead a holistic approach of diagnosis. Because of this fundamental difference, modern medical professionals and modernizers attacked Chinese medicine as lacking scientific foundation and therefore labeling it useless superstition. The tensions between Chinese medicine and Western medicine were not merely medical competition but political and cultural contentions as well. This book shows that Chinese medicine faced the crisis of being eliminated by the modern authorities three times in 1914, 1929, and the early 1950s respectively, all in the name of modernization and science. The modern transformation of Chinese medicine illustrates the history of Chinese modernization and vice versa. In their recent books on the modernization of Chinese medicine, Sean Hsiang-Lin Lei investigates the tension and divide of Chinese and Western medicines and shows how practitioners of Chinese medicine turned 
the challenges into a modernizing force to transform themselves into an organized modern profession, whereas Bridie Andrews concentrates on the adaptation and accommodation of both Western and Chinese medicines. ${ }^{20}$ Their scholarship further illuminates that medical developments were tied directly to the particular cultural settings and transformative modernization of China.

Modernizers of early twentieth-century China, including professionals of modern medicine, intellectuals, journalists, urban merchants and government officials, promoted Western medicine and public health with the political rhetoric of national strength and social progress. Vital statistics on national death rates provided them with the convincing data that public health was a critical element of modernity and nation strength, as advanced nations like the United States and Britain had low death rates, whereas weak nations like India and China had high death rates. The Western argument of economic gain in good health had little appealing power to the Chinese when their country was being dismembered by foreign powers. The first and utmost concern of the Chinese was the fate of their country in the face of foreign powers' scramble, and their attention to medicine and public health was stimulated by the larger political issues of national sovereignty. Of the first resolutions of the National Medical Association of China (NMAC, 中华医学会) upon its creation in 1915, was the request for the Chinese government to set up a modern Public Health Service to take care of national health, as did all advanced nations. The NMAC defined its mission as serving the nationalist effort to modernize and strengthen China by advocating modern medical science and arousing public interest in public health and preventive medicine. The Chinese medical association has been champion of public health throughout the twentieth century, which differed from their counterpart in America. ${ }^{21}$ It played an active role in the early public health education campaigns and emphasized national health and national strength as the theme of health education. ${ }^{22}$ Dissemination of public health information also served to promote science and Western medicine in Chinese society where people relied on Chinese medicine and had little knowledge of Western medicine. The medical field became a contesting ground of different political forces that pitted progress and modernity against backwardness and tradition. Progress and national strength were constant themes in the promotion of Western medicine as the scientific true knowledge in contrast to the attacks on Chinese medicine as unscientific superstition and backward tradition. In the early twentieth century, science attracted Chinese intelligentsia with significant meanings of cultural modernity in their search for a new national identity and order. When Western ideas and scientism increasingly shaped Chinese intellectual and political thinking, support of modern medicine and public health meant politically progressive and intellectually modern.

Chinese intellectuals launched frontal attacks on traditional culture while embracing science as the new culture during the New Culture and the May Fourth Movements. Science gained the cultural authority to define the truth not only in the medical field but also in every aspect of social, political and economic life. In the iconoclastic revolutionary transition from the traditional cultural mold to the new age of science, concepts of science and modernity became the driving force 
to orient Chinese intellectual pursuit and political revolution. ${ }^{23}$ Intellectual modernizers considered the contention between Chinese and Western medicines not a question of medical profession but a political fight between the old and the new, the backward and the progressive, and the traditional and the modern. Chinese medicine was considered the symbol of old culture while Western medicine the practice of science and measure of modernity. The attacks on Chinese medicine and tradition influenced the young students in their critical view of Chinese medicine as things of the past. Attempts to promote Chinese medicine were identified with warlords' political militarism to return China to the past and to obstruct the revolutionary endeavor of the Nationalist Party (GMD, Guomindang). The new "cultural authority" of science was reshaping China's intellectual thinking, social values and political ideologies. ${ }^{24}$ Science even became an "ideological identity' of the revolutionaries against the conservatives, permeating the medical front as well as the political and social and cultural domains. ${ }^{25}$

Both the Nationalist Party and the Chinese Communist Party (CCP, Gongchandang) embraced science as the foundation of their ideologies and promoted science in their revolutionary visions for a new society. Modern medicine and hygiene and public health were important parts of the revolutionary goals of the two political parties, but their divergent political beliefs guided their respective revolutions and state-building through different routes of national mobilization and reconstruction. The Nationalists established a government in Nanjing and continued the promotion of national health for a strong China by undertaking systematic modernization of medicine and health institutions. Significant accomplishments were the creation of a national health administrative system with the policy of state medicine and the establishment of medical training and research facilities. The Ministry of Health of the Nationalist government attempted the extreme action of abolishing Chinese medicine once for all, which intensified the confrontation between Chinese medicine and Western medicine but stimulated practitioners of Chinese medicine to unite and fight with new energy and modern political tactics. Jiang Jieshi, leader of the Nationalist Party and government, did not take serious interest in health modernization but emphasized personal hygiene and civilized behavior in the New Life Movement to shape the modernization of Chinese society. The Nationalist government focused on institutional building as the center of health modernization, and neglected to undertake land reforms to address the major socio-economic problems of poverty and subsistence living that were fundamental to public health.

The CCP launched health movements in their revolutionary bases in rural China, and emphasized disease prevention as an important aspect to preserve revolutionary force and better people's lives. The CCP health programs were guided by their socialist political ideology and vision of an equal society. To improve people's health conditions was one significant goal of the overall social reforms, as the revolution aimed to transform not only the socio-economic institutions but also the thinking and attitude of people from the old feudal and superstitious mode to the modern and scientific outlook of socialism. Hygiene and public health were advocated as important components of the revolutionary 


\section{Introduction}

cause and were integrated in the activities of socioeconomic development in the CCP regions. Mao Zedong, leader of the CCP revolution, took a great interest in medicine and public health and wrote frequently to promote the importance of public health and the development of a new CCP-led society. In contrast to the Nationalists, the CCP made use and encouraged the integration of Chinese medicine and Western medicine in its revolutionary transformation of China. Prevention of disease and the unity of Chinese and Western medicines were key elements of the national health principles of the People's Republic of China in the creation of a people's healthcare system. The integration of Western and Chinese medicines was not without opposition from the health leaders in the early 1950s but the intervention of political leaders in the modernization of Chinese medicine with scientific knowledge led to the unique accomplishments of creating a new medicine called the integrative medicine (中西医结合), which co-exists with Western medicine (xiyi, 西医) and Chinese medicine (zhongyi, 中医) to benefit Chinese people today. The PRC made the extraordinary achievement of providing free healthcare to the large Chinese population with low costs in the 1950s-1970s. Dozens of major epidemic diseases, such as smallpox, plague, cholera, typhus, typhoid, polio, kala-azar, filariasis, schistosomiasis, tuberculosis and malaria, were either eradicated or brought under basic control. With accessible healthcare and improved living standards, people's health significantly improved with life expectancy increased from 38 in 1949 to 65 in 1975. China was considered a model for the developing world with the creation of a low-cost healthcare system.

The post-Mao economic reforms fundamentally shifted the foundation of economic structure through privatization and marketization. As a result, the people's healthcare that had been built upon the socialist collective economic system collapsed and the country experienced a healthcare crisis, with some old epidemic diseases re-emerging as health threats and high medical costs sending families into poverty. After the use of market forces to reform the health sector failed, the government introduced a comprehensive health system reform plan in 2009 and is continuing to deepen the health system reform. It's a challenging but imperative task for current Chinese modernizers to make the health system reform successful when they deliver the promise of a good life in a fair and just society under a new modernization paradigm.

\section{Government policies and health institutions}

Public health has been a vital component of the institutional building of a modern state and a transformative force to change people's attitude, values, and behavior.

The demand for the Chinese government to establish a modern sanitary administration initially came from foreign powers during the negotiations of returning of cities to China in the wake of suppression of the Boxer Uprising. The Beiyang Sanitary Service (北洋防疫处) was established in 1902 under the pressure of foreign powers and China's struggle to modernize and remain 
sovereign. This initiation of creating a government public health institution differentiated China from the West in the endeavor of public health administration, and underscored the issues of national sovereignty and struggle against foreign dominance in China's public health modernization. Within China, foreign powers enjoyed the authority of controlling public health at treaty ports in addition to many other privileges under the unequal treaty system. ${ }^{26}$ Public health issues were often dealt with by the Ministry of Foreign Affairs rather than the Ministry of Interior of the late Qing government. As public health administration became a gauge to measure progress and modernization efforts at the turn of the twentieth century, both central and local governments set up public health institutions to project their progressive and modern image. Sometimes, local government went a step ahead of the central government in sponsoring and enforcing public health programs, especially in cities where Western influence was strong. The late Qing's decision to establish the Beiyang Sanitary Service came as part of the modernization programs of "New Policy." Yuan Shi-kai played a leading role in the modernization programs, despite his controversial place in modern Chinese history. He experimented with creating a variety of modern institutions, such as those of sanitation, police, education and the military, before the Qing court took steps in this direction. When he was Viceroy of Zhili, Yuan even set up the first women's medical department in Tianjin to take charge of a government-run women's medical school with a hospital. When a plague epidemic broke out in northeast China in 1910, the fight to control the plague was complicated by international intrigues of the powers to undermine Chinese sovereignty. When the Chinese medical scientist Wu Liande became the leader of the new North Manchurian Plague Prevention Service in 1911, China asserted its ability in modern administration of epidemic control and its sovereignty on the international stage.

The demise of the Qing dynasty signified not only the political transition from the dynastic imperial system to a modern polity of republic but also the creation of a new knowledge system of medicine and public health based on science. As president of the new Republic, Yuan Shikai favored modern medicine at the expense of Chinese medicine to publicize his government's political progressiveness and himself a committed modernizer of China. Presidential orders and government regulations were issued regarding the standards of food hygiene, sanitation, public safety, and the practice of midwifery. Yuan's support for modern medicine even led to the first attempt to abolish Chinese medicine in 1914. When the government promulgated "Regulations on the Prevention of Infectious Diseases" and the "Regulations on Medical and Pharmaceutical Examinations" in 1916, it took on the modern responsibility of fighting epidemics and standardizing medical practice. Given the chaotic and weak government of the early Republic, these regulations were not effectively enforced, but they set up the legal obligations of the government to public health.

The call for the state to take responsibility of national health grew when medical scientists and intellectuals actively voiced their opinions to shape government policies from their professional positions in modern public health institutions, 


\section{Introduction}

such as the North Manchurian Plague Prevention Service, and the Central Epidemic Prevention Bureau. In the decades of the 1920s-1940s, scientific and medical professionals played a crucial role in the building of health institutions of a modern state. As science held unique significance for Chinese modernization, the promotion of Western medicine as the scientific medicine made it the choice for Chinese medical modernization, while Chinese medicine was excluded from the construction of a modern health system under the Nationalist government. The Nationalist elite with Western medical training formed the key force of health modernizers who worked with the League of Nations Health Organization (LNHO) and the Rockefeller Foundation in building an institutional structure of a centralized health administration based on modern medicine. In an attempt to make a clean slate for health modernization, the Nationalist medical elite decided to abolish Chinese medicine in 1929, only to be challenged by the unity of the Chinese medical world. The "old-style" Chinese medicine men were quite modern in their fight for Chinese medicine as they organized popular protests and political lobbying and gave the medicine a new name, "national medicine 国医.” In the end, the Nationalist medical elite managed to exclude Chinese medicine from playing a role in the construction of a modern health system, despite their failure to abolish it. Working with the LNHO, the Nationalist health leaders decided on state medicine as the model for China, but they diverged in interpreting the meaning of state medicine when designing its delivery. While those who were doing the fieldwork of public health advocated health service to all people, the health bureaucrats concentrated on the institution building of a central health administration. The primary emphasis on institutional building could be attributed to factors such as bureaucratic convenience, limited manpower to provide medical and health service, and the lack of political commitment to a national health service. The Nationalist health modernizers, nevertheless, created an impressive modern national health administration system with research and training. Using health stations as pilot programs to conduct studies of sanitation and health, they gathered data of vital statistics and health, which lent the modern state the authority to exercise regulations of the health behavior of the public in the name of modernity and progress. ${ }^{27}$ The Nationalist health system had segments of central and local health institutions, where the central institutions were systematically developed with international assistance, and the local institutions developed under the supervision of provincial governments without uniformity of standards. The Nationalist health modernizers were least successful in rural health construction, even though they had laid out detailed plans of a xian (county) centered rural health system. According to their plan, each xiancheng (county town) would have a center hospital to perform the simple health work of epidemic prevention, basic medical service, midwifery, health education and anti-opium smoking. The health work of a county center hospital would extend into villages with each rural district having a health station, and each village town a sub-station, and each village a health worker. These beautiful ideas of a three-tiered rural health structure, however, remained largely on paper under the Nationalist rule but were put into practice by the CCP government. 
The Chinese Communist movement was located in rural areas in the 1920s-1940s, where the CCP health workers had limited medical resources but created a variety of health programs and services to meet the needs of the CCP military and local population. The CCP health policy emphasized prevention and the use of both Western and Chinese medicines. Health programs were integrated into the social reforms movements in their revolutionary bases where activities of literacy, land reform, women's liberation, and dissemination of revolutionary ideas were incorporated in the mobilization of peasants to participate in sanitation and health movements to prevent diseases. The CCP leaders valued Chinese medicine and encouraged the mutual learning of Western and Chinese medicines. In Yanan, medical doctors established the Society of National Medicine Studies (国医研究会) and the Association of Chinese and Western Medical Research (中西医药研究会). Health institutions were built, which included hospitals, medical schools, Chinese health and medical clinics, and people's health cooperatives for treatment and prevention. The CCP even tried to build a rural health system, quite similar to the Nationalist plan but on a modest scale, with a health station at each county (xian, 县), a health worker at a rural district, and a health committee in a village, making a three-tiered rural health network.

After the People's Republic of China was established in 1949, the central government formulated a national health policy with four key principles based on the CCP revolutionary vision and practice during the war time: (1) serving the needs of workers, peasants and soldiers, (2) prevention as the first priority, (3) uniting Chinese and Western medicines, and (4) combining health work with mass movement. In delivering the revolutionary health policy and commitment to people's healthcare, the government built diverse national systems of hospitals, clinics, health stations, maternal and child health stations, and health and epidemic prevention stations. Rapid expansion of medical education based on the Soviet model produced large numbers of medical and health professionals to meet the urgent needs of a large population. The three-tiered rural health system was made to work with the training of millions of part-time health workers called "barefoot doctors" to serve their fellow villagers with Western and Chinese medicines. Free healthcare at low costs was provided through two types of economic relations: employees of government and state enterprises (全民所 有制人员) enjoyed healthcare at public expenses, while employees of collective enterprises (集体所有制人员) including small businesses and rural communes enjoyed healthcare at collective expenses.

Economic reforms since 1978 introduced private practice of medicine into the society. Private hospitals were established in cities and county towns to compete with public hospitals. Rural health workers including barefoot doctors were transformed into village doctors who conducted private medical practice at their own clinics with fees charged for service. The creation of private medical practice and institutions is supposed to encourage better quality and accessibility through market forces of competition, but the reality was far from the theoretical proposition, where high medical costs and low quality of service remain the two 
major complaints about the current health system. Enforcement of standardization and quality of operation badly need to be improved.

\section{Health education and propaganda}

Previous discussion has made clear that health modernization was integral to the political and social reforms and revolutions over the century-long struggle of China. Early propagation of health and cleanliness was promoted by local elites in treaty ports. The Chinese elite expounded cleanliness to excoriate their fellow countrymen to take action to improve themselves in the face of foreign criticism of unsanitary China. Chinese reformist and revolutionary intellectuals, influenced by the ideas of Social Darwinism and modern hygiene, wrote extensively to promote physical health and hygiene for the sake of reviving the nation. A major health education campaign was carried out in the 1910s when local government worked with the Council on Health Education to disseminate modern health knowledge and disease prevention. A large collection of health education material was created for the campaigns, which included health literature and visual material, such as bulletins, leaflets, posters, lecture charts, books, lantern slides, films, and exhibit items of the "health shows." Although there was little explicit explanation of the science of germ theory in the campaign, the idea of disease transmission via agents like flies was popularly demonstrated and displayed. Health programs, such as anti-tuberculosis and anti-cholera campaigns, better baby weeks, vision conservation, smallpox vaccination and health examination in schools, were carried out in urban cities. ${ }^{28}$ National health essay contests were also organized among students to discuss national health and national strength. The methods and material of early popular health education of the Council on Health Education laid the ground work for health education and propaganda of the Nationalists and the Communists in the following decades.

The dissemination of public health and modern medicine promoted the direct link between personal health, public good, and national strength. It attracted various social groups and helped raise people's consciousness of sanitation, disease prevention, and the importance of public health in the overall modernization effort of building a strong nation. Newspapers and popular magazines frequently reported and commented on medicine and public health, broadly influencing public information of disease prevention, particularly during the outbreaks of epidemics. Dagongbao (Ta Kung Pao, 大公报) and Shenbao (申报), two major newspapers in China, published medical weeklys (医学周刊) to disseminate medical knowledge and hygiene, contributing to public interaction with the latest health and medical development. The government began popular education about disease transmission after the 1910 outbreak of a pneumonic plague epidemic in northeast China. A large quantity of anti-plague placards and pamphlets and public health notices was printed and distributed to instruct people on the methods of preventing plague from entering their communities and villages. The written educational material, however, accomplished little, due to the high illiteracy of people. In the meantime, media reports of the deadly plague 
epidemic caused widespread fear but stimulated calls for sanitation and prevention across the country. Monetary rewards were offered for catching mice, which were thought the culprits, only to find that Siberian marmots had transmitted the plague, possibly to bring revenge on humans who had been killing them for their highly desired fur.

The plague fight motivated more intellectuals and medical scientists to advocate public health education and broader social reforms. They felt the urgent need to educate the public about the scientific knowledge of medicine and modern preventive methods and blamed the ignorance (愚昧) and superstition (迷信) of people for not following anti-plague measures of disinfection and isolation. Medical scientists delivered public lectures on personal hygiene and disease prevention and wrote about these subjects in newspapers and popular magazines. Their explanation of the precise causation of disease popularized germ theory and modern medicine and made disease prevention a modern behavior of social progress. Popular education on germ theory and the new terminology associated with science took a prominent place in the New Culture and the May Fourth Movements when vernacular (baihua, 白话) writing was promoted to convey new ideas to the masses. Cities saw the rise of popular education institutes and health organizations where public lectures and exhibits were held to demonstrate new ideas and concepts. Health circulars and notices emphasized the danger of chuanran (传染, transmission) of diseases via germs, which were explained as tiny bugs. Public health bulletins explained the necessity of isolation and quarantine when family members were found infected because of chuanran. Scientific terms, such as germ, virus, microbe, pest, microscope, and contagious disease were popularized in vernacular health circulars and notices. Through newspapers, public lectures, health bulletins and vernacular circulars, concepts of germs and disease transmission were repeatedly conveyed to the public for the purpose of disease prevention and health protection.

The Nationalist government carried out extensive health education and propaganda with the clear guidance of GMD party ideology and modernization programs. ${ }^{29}$ Health propaganda evoked Sun Yat-sen's three people's principles as the political rhetoric. ${ }^{30}$ The Health Bureau of Nanjing claimed, in its publication, Hygiene of the Capital (首都卫生), that the state had the moral responsibility to protect the health of people in four basic areas of needs-food, clothing, shelter, and transportation (衣食住行). The Propaganda Department of the GMD Central Executive Committee compiled and published a "Propaganda Guide for the Health Movement” [卫生运动宣传纲要] in 1929, which promoted health movement as the movement of national independence, the movement of national salvation, and the movement of liberation. The guide informed people that national competition for existence had entered the most urgent moment and there were six key elements of competition: physique, intelligence, bravery, vigilance, tenacity, and unity. It instructed that the health movement must be popularized among the masses and conducted scientifically. ${ }^{31}$ The GMD health advocates expounded that the foundation of national health depended on people's understanding that health was intertwined with the weal and woe of the Chinese nation and race. 
In line with Sun Yat-sen's vision of different stages of national construction, the GMD propagandists planned three stages of propaganda (宣传), training (训练), and awakening (唤醒) for the long-term effect of health education for the ordinary people. A wide variety of methods was used in propaganda work but mainly divided into written and oral categories. Written material included health leaflets and booklets, posters, slogans and charts of vital statistics, while oral activities featured indoor lectures by celebrities and health professionals, traveling outdoor lectures by government officials and professional groups, and the use of slangs and songs for women and children. Health exhibits of popular education included various kinds of health pictures, posters, slogans, images of microbes, charts of diseases and vital statistics, and model devices of pathology. Radio talks on health were created to reach broader audience and were given by medical professionals. Short courses on health rules were offered to people of different trades, particularly those of restaurants, teahouses, bathhouses, barber shops, theaters and hotels, whose work directly impacted public health. Teachers were trained to give lessons on hygiene and public health, and to facilitate school health services. In the work of awakening, government-sponsored cleanliness campaigns took the center-stage of health propaganda in cities, where government officials led the city-wide cleanliness campaigns with meetings, parades and slogans to remove refuse and dirt on the streets. Disinfections, anti-pest movements against mosquitos, flies, fleas and rats were also carried out in urban districts and schools. Smallpox vaccinations were provided during health campaigns. The Nationalist health campaigns happened primarily in major cities, although a few county towns held sporadic campaigns of cleanliness in response to government calls.

While the Nationalist health propaganda attracted and educated mostly urban middle classes, the Communists worked with peasants to integrate health programs into the overall social reforms and revolution in their controlled areas. The CCP health propaganda addressed poverty, sanitation, literacy, women's equality, nutrition and farming production with the advocacy of hygienic and sanitary practice as revolutionary activities to transform traditional institutions and old habits and norms. The CCP adopted "prevention first" policy and encouraged all possible means to educate and mobilize the soldiers and the masses to get rid of major epidemic diseases. The CCP soldiers carried out hygiene-week programs with locals to do general cleaning while disseminating health and revolutionary information. The CCP's “Guide of the Health Movement” in 1933 promulgated that filth and disease were part of the problems of people's sufferings that had to be solved. It called on local governments and mass organizations to lead the people to fight against filth, disease, and old ideas and habits of superstition. Methods of disease-reporting and isolation and disinfection were developed, and popular health contests were held among the masses. The CCP used familiar forms of folk entertainment, such as folk dances and songs, and short skits and shows, to convey messages against superstition, witch doctors, and unhygienic behavior. Health talks and exhibits on hygiene and disease prevention were held 
during festivals and temple fairs where more people were present. Mass mobilization and participation characterized the CCP hygiene campaigns and public health propaganda and education.

The CCP continued mass health movements across the country after the establishment of the PRC. Health propaganda emphasized health improvement as an integral experience of the overall socialist reconstruction to transform Chinese society. The Patriotic Health Movement mobilized people to take active roles to fight diseases while disseminating new government policies, social values and scientific information of health to change people's attitudes and behavior. Chinese medicine, after a brief marginalization in the early 1950s, was highly promoted with national pride as a valuable medical system, quite different from the Nationalist era. In urban cities, health campaigns carried out vaccinations and general sanitation and cleanliness in city districts, schools and work units; whereas in rural China, health campaigns combined preventive vaccinations and sanitary activities with land reclamation and irrigation construction. Visual materials of posters and pictorials were widely used to popularize scientific knowledge of disease through health education and literacy movement in the 1950s-1970s. Health campaigns also promoted hygienic behavior as expected virtues of socialist citizens and good health as essential for economic production and national defense.

The promotion of four modernizations in the era of economic reforms has shifted public health and disease prevention from mass mobilization to reliance on medical science and technologies such as vaccines and medication. The de-collectivization of economy and decentralization of the health system have left health education greatly to the care of individual consumers who take particular caution against health threats of environmental hazards and industrialized food. The long-term effect of public health education has not been lost, especially among the retired and elderly, for they go out and exercise in parks and at public squares out of their own will and initiative.

\section{Summary of chapters}

The chapters are organized chronologically, but each chapter unfolds with thematic discussions of key topics situated in larger social, political and cultural contexts. International and transnational interactions constitute a significant feature of China's public health movements and modernization. Chapter 1 explores Chinese understanding of public health as national power in the modern world. It examines the change of landscape from a traditional agrarian society to modern factories in treaty ports, where the formerly salubrious cities were eroded by environmental degradation, pollution, slums, disease and filth of a typical industrializing urban setting. Modern facilities such as electricity, running water, sewage system, indoor plumbing, garbage collection and tall buildings with conspicuous wealth in foreign settlements contrasted sharply with poverty, crowdedness, filth, illness and disease, slums and cheap labor in the Chinese sections in the treaty ports. The divide of hygiene and modernity was not only expressed in the treaty port cities but also in the dealings of Chinese government 
with foreign powers. After the suppression of the Boxer Uprising, foreign powers set up provisional governments in major cities including Beijing and Tianjin. The return of the cities to China hinged on the Chinese government's agreement to modern reforms including the creation of sanitary administration. While the government initiated sanitary and public health administration under the pressure of foreign powers, private efforts in this regard had begun by local elite and literati since the late nineteenth century. Moreover, the 1910 plague epidemic triggered a widespread urban movement of sanitation to prevent plague, promoted mainly by local gentry and merchants as well as physicians of Western and Chinese medicines. Newspapers were influential in shaping public fear of the plague and actions of prevention. Chinese doctors of Western medicine collaborated with the YMCA and medical missionaries in carrying out major public health education campaigns in the 1910s to promote hygiene and disease prevention. The chapter examines the tensions of Chinese and foreign relations, traditional cultural norms and modern concepts, practice of sanitary and epidemic control, and the attempts of various groups to shape the future of China. These early efforts were influenced by Social Darwinian interpretations of personal health and national strength and the political implications of modern medicine and public health for the state and people.

Science lent the credibility and legitimacy of modern medicine and public health as essential elements of a modern nation. Chinese intellectuals, who started the New Culture and the May Fourth Movements in the 1910s-1920s, promoted science as the new cultural framework to re-invent China. Science also provided the cultural authority and identity of modernizers in the larger political and social movements to destroy the old world and create a new society of China. Modernization of medicine was not merely a medical matter but a political fight against reactionary forces in national revolutions. Chinese medicine, being integral to traditional culture, was considered an obstacle of holding China back from progress by radical intellectuals. In this context of cultural renaissance and ascendance of science entered the American medical enterprise of the Rockefeller Foundation, which exerted profound influence on the leaders of modern medicine in China. Chapter 2 studies these broad changes with attention to the Science Society of China and the intellectuals who shaped the new cultural orientation of scientism and vernacular (baihua) writing to popularize science among the masses, particularly the modern terminology of medical science and disease prevention during the outbreaks of epidemic diseases. Chinese intellectuals also started the Rural Reform and Mass Education Movement with pilot programs to integrate health modernization into the socio-economic development of rural reconstruction. The unique role of Peking Union Medical College in medical education and the training of public health leaders in China showed that the RF's medical enterprise focused on the production of health leaders, who eventually dominated the health bureaucracy and shaped the policies and development of the Nationalist health system.

Chapter 3 takes a close look at the construction of a modern national health system by the medical elite of the Nationalist government and the creative 
development of health programs by the CCP in their revolutionary regions. The LNHO and the RF provided significant assistance to the Nationalists in the institutional-building and professional-training of modern health. The Nationalist medical elite focused on building a modern health administrative system of institutions rather than the delivery of health service to people. They created beautiful designs of a national health system, even with a three-tiered rural health structure, but they were short on delivery, particularly in rural health construction. Extraordinary progress was made in establishing central medical research and training institutions but less successful in the development of local institutions during the politically tumultuous years of wars. The CCP, in contrast, built their revolutionary bases and worked with rural peasants on health programs from the bottom up. They relied on both Western and Chinese medicines in health service and encouraged the organization of health cooperatives and medical teams. With limited resources in medicine and professionals, they mobilized the masses to achieve health and social reforms. International aid was important to the CCP health development when medical assistance from different groups of the antifascist movement during World War II helped raise the standards of medical practice with new knowledge and technical equipment.

Chapter 4 examines the PRC's health development as an integral part of the socialist reconstruction of China. The alleged American germ-warfare during the Korean War had an unexpected impact on Chinese health policy and antidisease movements. The Patriotic Health Movement combined national defense with disease prevention and provided the masses with the rally of political enthusiasm and national pride in carrying out activities of sanitation and anti-disease campaigns. Health movement became a patriotic political movement for national defense, economic production, and people's health in the overall transformation of social institutions and people's attitude and behavior. Through mobilization and the literacy movement, the masses learned the scientific knowledge of disease and health, and took an active role to fight disease and improve society and themselves. With the rapid development of diverse medical and health institutions, the health service was extended into rural villages with the training of millions of health workers in both Western and Chinese medicines, some of them part-time rural paramedics called barefoot doctors to serve fellow villagers. Free and lowcost healthcare was delivered to people through work-units and the rural commune system. What the Nationalist health planners had dreamed in their designs of a modern health system was now delivered by the health workers of the PRC in an actual health service. Thanks to the rural cooperative medical system, China was able to provide primary healthcare to 22 percent of the world population by using only 1 percent of health resources. China's low-cost healthcare system was hailed the model for developing countries that faced serious health challenges.

The economic reforms since the end of 1970s have fundamentally dismantled the socialist health system of free healthcare for the people. Instead, a health insurance system was introduced as part of the reform of the health sector. The result was a rapid increase of medical costs and inaccessibility of medical service in China, which gave rise to nation-wide complaints of the current health 


\section{Introduction}

system and health service. The government has acknowledged the failure of health reforms in the 1990s and has issued a new reform plan of the health system in 2009. Chapter 5 discusses the marketization of economy and the collapse of the socialist healthcare system. It examines the operations and challenges of the New Rural Cooperative Medical System that was initiated in the beginning of the twenty-first century and the continuing efforts of the government to reform and re-build a health system with the provision of primary healthcare to people.

\section{Notes}

1 “On Hygiene," Hankou ribao [Hankow Daily], the 8th day of the Fifth month, reprinted in Dongfang zazhi [Eastern Miscellany], vol. 2, no. 8 (1905), 156-157.

2 British newspapers began to use the phrase "the sick man of the Orient" to describe China in 1896. Other newspapers followed suit. Several variations of the phrase, such as "the sick man of Huaxia," and "the sick man of East Asia," were in circulation at the beginning of the twentieth century according to Gao Cui (see his book, From "The Sick Man of East Asia" to A Strong Country of Sports [Cong "dong ya bing fu" dao ti yu qiang guo] (Sichuan renmin chubanshe, 2002), 9-12. In 1905, The New York Times (16 August 1905, 6) reported under the title "The Sick Man of the Far East": "China will henceforth be put in the same position in which Turkey has been for half a century. ... She will become, by the ratification of the proposed treaty of peace, the Sick Man of the Far East." Western scholars usually use the phrase "the sick man of Asia."

3 Ruth Rogaski, Hygienic Modernity: Meanings of Health and Disease in Treaty-Port China (Berkeley CA: University of California Press, 2004).

$4 \mathrm{Hu}$ Cheng, “The Image of the 'Unsanitary' Chinese: Differing Narratives of Chinese and Foreigners - Observations of Public Hygiene in Shanghai, 1860-1911,” Bulletin of the Institute of Modern History Academia Sinica, vol. 56 (2007),1-43.

5 Brett Bowden, The Empire of Civilization: The Evolution of an Imperial Idea (University of Chicago Press, 2009). See also, his Civilization: Critical Concepts in Political Science, 4 volumes (Routledge, 2009).

6 For the role of newspapers in shaping up public opinion and sentiment, see Joan Judge, Print and Politics: "Shibao" and the Culture of Reform in Late Qing China (CA: Stanford University Press, 1996); and Henrietta Harrison, "Newspapers and Nationalism in Rural China, 1890-1929,” Past \& Present, vol. 166 (2000), 181-204.

7 George Rosen, A History of Public Health, expanded edition (Baltimore: The Johns Hopkins University Press, 1993), 168-270; and Richard H. Shryock, The Development of Modern Medicine (Madison, WI: University of Wisconsin Press, 1980).

8 The three people's principles are people's nation (民族), people's rights (民权), and people's livelihood (民生).

9 Barry Buzan and George Lawson, The Global Transformation: History, Modernity and the Making of International Relations (Cambridge: Cambridge University Press, 2015).

10 Opium was always associated with the decline of China in the nineteenth century when China failed to stop the illegal drug traffic even by fighting the Opium War with Britain (1839-1942). In view of the wide-spread use of opium among Chinese people, physical well-being struck a painful cord in the national psyche but conveyed a unique meaning in the particular situation of China. The discourse of Chinese anti-opium movements concentrated on opium and the decline of China - the national shame and disaster. The Nationalist government launched anti-opium campaigns with anti-opium offices established in many counties; and the PRC government eradicated the opium epidemic in the 1950s via mass education and rehabilitation programs. Works on anti-opium movements include Alan Baumler, The Chinese and Opium under the Republic: Worse than Floods and Wild Beasts (Albany, New York: State University of New York Press, 2008); 
and Kathleen Lodwick, Crusaders against Opium: Protestant Missionaries in China, 1874-1917 (Lexington, KY: University Press of Kentucky, 2009). Tobacco smoking has developed into a social habit in China and the anti-smoking movement has recently gained momentum after its health hazards are aggressively publicized. Carol Benedict has written a history of tobacco smoking in China, Golden-Silk Smoke: A History of Tobacco in China, 1550-2010 (Berkeley, CA: University of California Press, 2011). On anti-smoking movements in China, see Liu Wen Nan, Jindai Zhongguo de bu xi zhiyan yundong yan jiu [The Anti-Cigarette Campaigns in Modern China] (Beijing: Shehui kexue wenxian chubanshe, 2015).

11 Tan Chung, "Imperialism in Nineteenth-Century China (II)-The Unequal Treaty System: Infrastructure of Irresponsible Imperialism,” China Report, vol. 17, no. 5 (1981), 3-33.

12 "Biographical File of W. W. Peter," Kautz Family YMCA Archives, University of Minnesota (hereafter YMCA Archives). The medal was awarded to people who had made significant beneficiary contributions to Chinese society.

13 The medal was displayed at a first-floor reading room at the Rockefeller Archives Center, North Tarrytown, New York.

14 Shirley S. Garrett, Social Reformers in Urban China: The Chinese Y.M.C.A., 1895-1926 (Cambridge, MA: Harvard University Press, 1970); and Noel H. Pugach, "Standard Oil and Petroleum Development in Early Republican China,” The Business History Review, vol. 45, no. 4 (Winter 1971), 452-473.

15 John Farley, To Cast Out Disease: A History of the International Health Division of the Rockefeller Foundation, 1913-1951 (New York: Oxford University Press, 2004).

16 Mary E. Ferguson, China Medical Board and Peking Union Medical College: A Chronicle of Fruitful Collaboration, 1914-1951 (New York: China Medical Board of New York, Inc., 1970), Appendix C, 245-253; and Mary Bullock, An American Transplant (Berkeley, CA: University of California Press, 1980), Appendix A, 233-237.

17 Margherita Zanasi, "Exporting Development: The League of Nations and Republican China," Comparative Studies in Society and History, vol. 49, no. 1 (2007),143-169.

18 Edmund S. K. Fung, The Intellectual Foundations of Chinese Modernity: Cultural and Political Thought in the Republican Era (Cambridge: Cambridge University Press, 2010).

19 Liping Bu, “Social Darwinism, Public Health and Modernization in China, 1895-1925" in Uneasy Encounters: The Politics of Medicine and Health in China 1900-1937, ed. Iris Borowy (Germany: Peter Lang, 2009), 93-124.

20 Sean Hsiang-Lin Lei, Neither Donkey nor Horse: Medicine and the Struggle over China's Modernity (Chicago: University of Chicago Press, 2014); and Bridie Andrews, The Making of Modern Chinese Medicine, 1850-1960 (Vancouver: University of British Columbia Press, 2014).

21 Paul Starr, The Social Transformation of American Medicine: The Rise of a Sovereign Profession and the Making of a Vast Industry (New York: Basic Books, 1982).

22 Liping Bu, "Public Health and Modernisation: The First Campaigns in China, 1915-1916,” Social History of Medicine, vol. 22, no. 2 (2009), 305-319.

23 Chow Tse-tung, The May 4th Movement: Intellectual Revolution in Modern China (Cambridge, MA: Harvard University Press, 1960).

24 On science as the cultural authority, see Gyan Prakash, Another Reason: Science and the Imagination of Modern India (Princeton University Press, 1999).

25 On the ideological identity of science, see Peter Buck, "Western Science in Republican China: Ideology and Institution Building," in Science and Value: Patterns of Tradition and Change, eds. Arnold Thackery and Evertt Menddelson (NY: Humanities Press, 1974), 159-184.

26 According to the Qing government's treaty agreements with foreign powers, Commissioner of the Maritime Customs Service of the Chinese government was 


\section{Introduction}

designated to a foreigner, whose authoritative power included, among other things, supervision of public health concerns such as quarantine during an epidemic. This treaty arrangement continued until the reorganization of Customs Services and the full tariff autonomy by the Nationalist government in 1928. Public health concerns including treaty ports' quarantine was under the supervision of the Customs Commissioner and the Customs Medical Officer. For instance, "the Quarantine Service in Shanghai was part of the Customs Service. Any quarantine action by the Port Health Officer must be acceptable to the Treaty Port Consuls, who often misused their extraterritoriality rights to protect the trade of their own nationalities at the expense of life during an epidemic.” (See I. C. Yuan, "Doctor J. Heng Liu: Our Leader and Organizer of National Health Services," in Dr. J. Heng Liu and Meidical and Health Development in China, ed., Irene Ssu-chin Liu Hou, Taiwan Shangwu Yingshuguan, 1989), 181.

27 Health stations were sometimes called health demonstration units, centers, or areas. For the sake of convenience and less confusion, I use health station to describe them all.

28 Liping Bu, "Cultural Communication in Picturing Health: W. W. Peter and the Public Health Campaigns in China, 1912-1926,” in Imagining Illness: Public Health and Visual Culture, ed., David Serlin (Minnesota: University of Minnesota Press, 2010), 24-39.

29 For a study of local propaganda work of the Nationalists, see Christopher A. Reed, "Propaganda by the Book," Frontiers of History in China, vol. 10, no. 1 (March 2015), 96-125.

30 Huang Wen, Three People's Principles and Medicine (Shaoguan, Guangdong: Shijie luntanshe, 1943).

31 Propaganda Guide for the Health Movement (Nanjing: Propaganda Department of the GMD Central Executive Committee, 1929). 